\title{
PENERAPAN $e$-PROCUREMENT DALAM PROSES PENGADAAN BARANG DAN JASA PEMERINTAH GUNA MENDUKUNG KETAHANAN TATA PEMERINTAHAN DAERAH (Studi Pada Unit Layanan Pengadaan Barang Dan Jasa Pemerintah Kabupaten Penajam Paser Utara Provinsi Kalimantan Timur)
}

\author{
Rahmat Hidayat \\ Pemerintah Kabupaten Penajam Paser Utara, Kaltim \\ e-mail: praja.rahmat@gmail.com
}

\begin{abstract}
The purpose of this study was to analyzed the application of the principle of e-Procurement in Procurement Services Unit in the Government District Penajam Paser Utara, examines the obstacles faced by the Procurement Services Unit in the process procurement of goods and services by the government through e-procurement process and to formulated strategies that were done overcome by Procurement Services Unit to the obstacles in implementation of e-procurement to supported the resilience of governance in the district Penajam Paser Utara.

The research method used was descriptive method with quantitative and qualitative approaches. The data was collected through questionnaires, interviews, observation and documentation. The measurement applied Likert scale was applied to 32 Procurement Services Unit officers and informant interviews to 3 people who knew in depth about the implementation of e-procurement in Penajam Paser Utara.

The research showed the application of the principles of e-procurement in district Penajam Paser Utara district that generally was going according to applicable regulations, but there were still some obstacles in its application, namely Procurement Services Unit institution, infrastructures, and human resources. It require the government efforts to resolve these obstacles in order to supported the resilience of regional governance in Penajam Paser Utara district.
\end{abstract}

Keywords : e-Procurement, The Resilience of Local Governance

\begin{abstract}
ABSTRAK
Tujuan penelitian ini untuk menganalisis penerapan prinsip e-procurement pada Unit Layanan Pengadaan Barang dan Jasa di Pemerintah Kabupaten Penajam Paser Utara, mengkaji kendala yang dihadapi Unit Layanan Pengadaan dalam proses pengadaan barang dan jasa pemerintah melalui proses e-procurement serta untuk merumuskan strategi yang dilakukan Unit Layanan Pengadaan dalam mengatasi kendala penerapan e-procurement guna mendukung ketahanan tata pemerintahan daerah di Kabupaten Penajam Paser Utara.

Metode penelitian yang digunakan yaitu metode penelitian deskriptif dengan perpaduan kuantitatif dan kualitatif. Teknik pengumpulan data dilakukan dengan penyebaran kuesioner, wawancara,observasi dan studi pustaka. Pengukuran menggunakan skala Likert kepada 32 orang petugas ULP dan wawancara kepada 3 orang informan yang mengetahui secara mendalam tentang penerapan e-procurement di Kabupaten Penajam Paser Utara.

Hasil penelitian menunjukkan penerapan prinsip e-procurement di Kabupaten Penajam Paser Utara secara umum sudah berjalan sesuai peraturan yang berlaku namun masih terdapat beberapa kendala dalam penerapannya, yakni kelembagaan ULP, Infrastruktur, dan SDM. Untuk itu diperlukan strategi pemerintah daerah dalam mengatasi kendala tersebut guna mendukung ketahanan tata pemerintahan daerah di Kabupaten Penajam Paser Utara.
\end{abstract}

Kata Kunci : e-Procurement, Ketahanan Tata Pemerintahan Daerah 
Rahmat Hidayat -- Penerapan E-Procurement Dalam Proses Pengadaan Barang Dan Jasa Pemerintah Guna Mendukung Ketahanan Tata Pemerintahan Daerah (Studi Pada Unit Layanan Pengadaan Barang Dan Jasa Pemerintah Kabupaten Penajam Paser Utara Provinsi Kalimantan Timur)

\section{PENGANTAR}

Kabupaten Penajam Paser Utaramerupakan salah satu daerah pemekaran di Provinsi Kalimantan Timur, sesuai dengan diterbitkannya UU No.7 Tahun 2002 tanggal 10 April 2002 tentang Pembentukan Kabupaten Penajam Paser Utara. Setelah pemekaran, Kabupaten Penajam Paser Utara terus berbenah diri untuk dapat melaksanakan segala ketentuan sebagai daerah otonom yaitu dalam penyelenggaraan urusanurusan pemerintahan, khususnya yang menjadi kewenangan Pemerintah Kabupaten Penajam Paser Utara.

Berkembangnya kebutuhan masyarakat menuntut Pemerintah Kabupaten Penajam Paser Utara untuk dapat menciptakan programprogram inovasi yang mampu menjawab tuntutan masyarakat secara efektif. Oleh karena itu, tuntutan untuk melaksanakan reformasi administrasi semakin tinggi. Salah satu yang menjadi sorotan Pemerintah Kabupaten Penajam Paser Utara untuk memperbaiki pelayanan publik yakni dalam hal pengadaan barang dan jasa.

Pemerintah Kabupaten Penajam Paser Utara terus menyempurnakan kegiatan pelelangan secara elektronik atau e-procurement. Hal itu dilakukan agar kepercayaan publik kepada aparat pemerintah di PPU dalam menjalankan roda pemerintahan dan pembangunan di daerah dapat berjalan sesuai dengan yang diinginkan. Demikian dikatakan, Plt. Sekda PPU, H Tohar saat membacakan sambutan Bupati PPU, H. Yusran Aspar ketika digelar pelatihan pengadaan barang dan jasa (barjas) serta ujian sertifikasi barjas pemerintah (http://www.korankaltim.com/pemkab-ppusempurnakan-e-procurement/).

Gambaran umum pengadaan barang dan jasa pemerintah di Indonesia khususnya di
Kabupaten Penajam Paser Utara masih dirasa tidak efisien dan transparan, karena adanya beberapa permasalahan dalam pelaksanaan pengadaan barang dan jasa, yaitu:

Pertama, kapasitas manajemen dan kelembagaan yakni kurangnya kapasitas dan integritas sumber daya manusia untuk mengelola pengadaan barang dan jasa. Hal ini sesuai kutipan informasi yang berasal dari media massa elektronik yang berjudul "Oknum ULP PPU Diduga Atur Pemenang Lelang, Penajam -Seorang oknum petugas tim Unit Lelang Pengadaan (ULP) Setkab Penajam Paser Utara (PPU) kedapatan mengarahkan pengaturan lelang, kepada pengusaha yang akan menjadi peserta lelang salah satu proyek" (http://m. inilah.com/news/detail/1777007/oknum-ulpppu-diduga-atur-pemenang-lelang).

Kedua, adanya intervensi oleh penyelenggara negara dalam hal ini oknum anggota legislatif dalam pengadaan barang dan jasa di Kabupaten Penajam Paser Utara. Berdasarkan informasi media massa elektronik yang berjudul “DPRD Penajam Paser Utara Intervensi Layanan Pengadaan Secara Elektronik (LPSE)" (https://harianmahakam. wordpress.com/2014/10/25/dprd-penajampaser-utara-intervensi-layanan-pengadaansecara-elektronik-lpse/).

Ketiga, belum optimalnya proses pengadaan barang dan jasa di Kabupaten Penajam Paser Utara. Proses pengadaan masih berjalan lamban sehingga menghambat proses pembangunan di Penajam Paser Utara. Hal ini sesuai dengan kutipan berita media massa elektronik yang berjudul "Sejumlah Lelang Proyek Lamban”(http://www.korankaltim. com/sejumlah-lelang-proyek-lamban/).

Beberapa permasalahan menunjukan indikasi inefisiensi ataupun korupsi pada 
proses pengadaan barang dan jasa pemerintah. Oleh karena itu, layanan e-procurement yang memanfaatkan teknologi informasi dan komunikasi menjadi sebuah instrument pendekatan yang strategis untuk memecahkan permasalahan tersebut sehingga diharapkan secara cepat dapat memperbaiki kinerja pengadaan barang dan jasa pemerintah di Kabupaten Penajam Paser Utara.

Berdasarkan latar belakang masalah di atas, dikaji "Penerapan E-procurement Dalam Proses Pengadaan Barang Dan Jasa Pemerintah Guna Mendukung Ketahanan Tata Pemerintahan Daerah (Studi Pada Unit Layanan Pengadaan Barang Dan Jasa Pemerintah Kabupaten Penajam Paser Utara Provinsi Kalimantan Timur)".

Adapun tujuan dari penelitian ini yakni: (1) Untuk menganalisis penerapan prinsip e-procurement pada Unit Layanan Pengadaan Barang dan Jasa di Pemerintah Kabupaten Penajam Paser Utara Provinsi Kaltim sesuai dengan Perpres 54 Tahun 2010. (2) Untuk mengkaji kendala yang dihadapi Unit Layanan Pengadaan Pemerintah Kabupaten Penajam Paser Utara dalam proses pengadaan barang dan jasa pemerintah melalui proses e-procurement. (3) Untuk merumuskan strategi yang dilakukan Unit Layanan Pengadaan Pemerintah Kabupaten Penajam Paser Utara dalam mengatasi kendala penerapan e-procurement guna mendukung ketahanan tata pemerintahan daerah di Kabupaten Penajam Paser Utara.

Penelitian ini menggunakan bentuk penelitian deskriptif dengan menggunakan perpaduan kuantitatif dan kualitatif. Deskriptif kuantitatif yaitu mendeskripsikan hasil penelitian dalam bentuk persentase, sedangkan deskriptif kualitatif yaitu mendeskripsikan hasil penelitian dalam bentuk kata-kata atau kalimat. Seperti yang diungkapakan oleh Narbuko dan Achmadi (2005: 44) bahwa penelitian deskriptif yakni penelitian yang berusaha untuk menuturkan pemecahan masalah yang ada pada saat sekarang berdasarkan data-data.

Tahap pertama peneliti menggunakan metode kuantitatif. Setelah selesai tahap pertama, kemudian melakukan penelitian dengan menggunakan metode kualitatif. Dalam penelitian ini, metode yang dominan digunakan yaitu kuantitatif. Oleh karena itu, teknik penggalian data utama melalui penyebaran kuesioner. Sementara metode kualitatif yang dilakukan melalui teknik wawancara dan observasi dilakukan sebagai pelengkap untuk mendukung data penelitian.

Pemilihan lokasi atau site selection menurut Sukmadinata (2007:102) berkenaan dengan penentuan unit, bagian, kelompok, dan tempat dimana orang-orang terlibat di dalam kegiatan atau peristiwa yang diteliti. Lokasi dalam penelitian ini yaitu Unit Layanan Pengadaan (ULP) Pemerintah Kabupaten Penajam Paser Utara, Kaltim.

Alasan dipilihnya lokasi penelitian ini karena Kabupaten Penajam Paser Utara merupakan salah satu kabupaten pemekaran yang ada di Kalimantan Timur sehingga termasuk dalam kabupaten yang sedang melaksanakan proses pembangunan di segala bidang, salah satunya ditempuh melalui pengadaan barang dan jasa pemerintah. Oleh karena itu, e-procurement dalam pengadaan barang dan jasa pemerintah guna mendukung ketahanan tata pemerintahan di Kabupaten Penajam Paser Utara, Kaltim.

Jenis data dalam penelitian ini terbagi menjadi dua, yaitu data primer dan data sekunder, data primer diperoleh melalui tiga cara yaitu melalui observasi, penyebaran 
Rahmat Hidayat -- Penerapan E-Procurement Dalam Proses Pengadaan Barang Dan Jasa Pemerintah Guna Mendukung Ketahanan Tata Pemerintahan Daerah (Studi Pada Unit Layanan Pengadaan Barang Dan Jasa Pemerintah Kabupaten Penajam Paser Utara Provinsi Kalimantan Timur)

kuesioner, dan wawancara, sedangkan untuk data sekunder lebih banyak diperoleh melalui studi terhadap penelitian dan literatur yang telah diterbitkan.

Penelitian ini berfokus pada penyelenggara negara dalam menjalankan e-procurement dalam hal ini Unit Layanan Pengadaan Kabupaten Penajam Paser Utara. Adapun metode pengambilan sampel dalam penelitian ini dibagi menjadi dua, yakni sebagai berikut: (1) Penentuan Responden. Penentuan pengambilan sampel apabila kurang dari 100 lebih baik diambil semua hingga penelitiannya merupakan penelitian populasi (Arikunto, 2008:116). Adapun responden dalam penelitian ini yakni seluruh petugas ULP Kabupaten Penajam Paser Utara yang berjumlah 32 orang. (2) Penentuan Informan. Dalam menetapkan informan menggunakan teknik snowball sampling. Snowball sampling adalah teknik pengambilan sampel dengan bantuan key-informan, dan dari key informan inilah akan berkembang sesuai petunjuknya. Dalam hal ini peneliti hanya mengungkapkan kriteria sebagai persyaratan untuk dijadikan sampel. (Subagyo, 2006:31). Informan dalam penelitian ini yakni: Sekretaris Daerah Kabupaten Penajam Paser Utara, Sekretaris Umum dan Sekretaris Teknis ULP Kabupaten Penajam Paser Utara.

Variabel yang digunakan adalah: (1) Variabel Bebas (Independent Variable). Dalam penelitian ini yang menjadi variabel bebas yaitu penerapan prinsip e-procurement dalam pengadaan barang dan jasa pemerintah. Penerapan prinsip e-procurement dalam pengadaan barang dan jasa pemerintah berdasarkan Perpres 54 tahun 2010, yaitu efisiensi, efektifitas, adil dan tidak diskriminatif, terbuka dan bersaing, transparan, akuntabilitas. (2) Variabel Terikat (Dependent Variable).
Dalam penelitian ini yang menjadi variabel terikat yakni Ketahanan Tata Pemerintahan Daerah di Kabupaten Penajam Paser Utara. Ketahanan tata pemerintahan daerah bisa dikaitkan dengan kemampuan pemerintah daerah dalam mencapai tujuan e-procurement berdasarkan Perpres 54 tahun 2010.

Analisis data yang digunakan adalah: (1) Analisis Data Kuantitatif. Data yang terkumpul dianalisis dengan teknik deskriptif yakni menyajikan hasil perhitungan statistik deskriptif berupa tabel frekuensi dan persentase yang didapat dari hasil penelitian. Dalam menganalisis data yang telah terkumpul dilakukan beberapa langkah yaitu penyuntingan data, pemberian kode, dan tabulasi. (2) Analisis Data Kualitatif. Data yang terkumpul dianalisis dengan alat analisis yaitu prinsipprinsip penerapan e-procurement berdasarkan Perpres 54 Tahun 2010 tentang Pengadaan Barang dan Jasa Pemerintah. Dalam penelitian ini, data yang telah terkumpul akan diolah. Proses ini terdiri dari tiga sub proses yang saling berkaitan yaitu data reduction, data display, dan conclusion drawing/verification (Miles dan Huberman, 1992:15-20).

\section{PEMBAHASAN}

\section{Logistik}

Konteks logistik identik dengan organisasi, pergerakan, dan penyimpanan dari material dan manusia. Domain dari aktivitas logistik sendiri adalah menyediakan sistem dengan produk yang tepat, di lokasi yang tepat, pada waktu yang tepat (right product, in the right place, at the right time) dengan mengoptimasikan pengukuran performansi yang diberikan contohnya meminimalisir total biaya operasional dan memenuhi kualifikasi yang diberikan sesuai dengan kemampuan dari 
klien dan sesuai dengan kualitas pelayanan (Ghiani, 2004).

Dalam Cetak Biru Pengembangan Sistem Logistik Nasional (Perpres No. 26 Tahun 2012), logistik didefinisikan sebagai bagian dari rantai pasok (supply chain) yang menangani arus barang, informasi, dan uang melalui proses pengadaan (procurement), penyimpanan (warehousing), transportasi (transportation), distribusi (distribution), dan pelayanan pengantaran (delivery services). Adapun penyusunan sistem logistik ditujukan untuk meningkatkan keamanan, efisiensi, dan efektfitas pergerakan barang, informasi, dan uang mulai dari titik asal (point of origin) sampai dengan titik tujuan (point of destination) sesuai dengan jenis, kualitas, jumlah, waktu dan tempat yang dikehendaki konsumen.

\section{Pengadaan Barang dan Jasa Pemerintah}

Pengadaan barang dan jasa (procurement) pada hakikatnya merupakan upaya untuk mendapatkan atau mewujudkan barang dan jasa yang diinginkan dengan menggunakan metode dan proses tertentu untuk mencapai kesepakatan harga, waktu, dan kesepakatan lainnya. Pengadaan dilakukan atas dasar pemikiran yang logis dan sistimatis, mengikuti norma dan etika yang berlaku, berdasarkan metoda dan proses pengadaan yang baku (Indonesia, 2005:5). Kegiatan pengadaan barang dan jasa ini dituangkan dalam suatu perjanjian atau kontrak pengadaan barang dan jasa.

Pengertian pengadaan barang dan jasa menurut Sutedi (2012:7) yaitu mencakup penjelasan dari seluruh proses sejak awal perencanaan, persiapan, perijinan, penentuan pemenang lelang hingga tahap pelaksanaan dan proses administrasi dalam pengadaan barang, pekerjaan atau jasa seperti jasa konsultasi teknis, jasa konsultasi keuangan, jasa konsultasi hukum atau jasa lainnya. Hal ini hampir sama dengan penjelasan dalam Peraturan Presiden Nomor 54 Tahun 2010, bahwa pengadaan barang/jasa pemerintah adalah kegiatan untuk memperoleh barang dan jasa oleh Kementerian/Lembaga/Satuan Kerja Perangkat Daerah/Institusi lainnya yang prosesnya dimulai dari perencanaan kebutuhan sampai diselesaikannya seluruh kegiatan untuk memperoleh barang dan jasa.

Berdasarkan Keputusan Presiden Nomor 54 Tahun 2010 tentang Pedoman Pengadaan Barang Dan Jasa Pemerintah, Prinsip-prinsip yang menjadi dasar dalam pelaksanaan kegiatan pengadaan barang dan jasa pemerintah yaitu efisien, efektif, terbuka dan bersaing, transparan, adil/tidak diskriminatif, dan akuntabel.

\section{Teori e-Procurement}

e-Procurement menurut Sutedi (2012:254) adalah sebuah sistem lelang dalam pengadaan barang dan jasa pemerintah dengan memanfaatkan teknologi, informasi dan komunikasi berbasis internet, agar dapat berlangsung secara efektif, efisien, terbuka, dan akuntabel. Hal ini hampir sama dengan penjelasan dari Indrajit yang dikutip oleh Andrianto (2007:218) bahwa e-procurement diartikan sebagai sebuah proses digitalisasi tender atau lelang pengadaan barang dan jasa pemerintah berbantuan internet. Definisi lebih sederhana disampaikan oleh Andrianto (2007:215), bahwa e-procurement adalah proses pengadaan barang dan jasa yang dilakukan melalui lelang secara elektronik.

Pengadaan barang dan jasa pemerintah secara elektronik atau via internet (e-procurement) merupakan salah satu 
Rahmat Hidayat -- Penerapan E-Procurement Dalam Proses Pengadaan Barang Dan Jasa Pemerintah Guna Mendukung Ketahanan Tata Pemerintahan Daerah (Studi Pada Unit Layanan Pengadaan Barang Dan Jasa Pemerintah Kabupaten Penajam Paser Utara Provinsi Kalimantan Timur)

mekanisme mewujudkan nilai-nilai good governance. Menurut Oliviera e-procurement adalah proses pembelian barang dan jasa yang diperlukan bagi kebutuhan operasional organisasi secara elektronik (Djojosoekarto, 2008:10). e-Procurement dalam pengertian umum diterapkan pada sistem data base yang terintegrasi dan area luas yang berbasis internet dengan jaringan sistem komunikasi dalam sebagian atau seluruh proses pembelian.

\section{Ketahanan Tata Pemerintahan Daerah Dalam Pengadaan Barang dan Jasa Pemerintah}

Ketahanan tata pemerintahan daerah merupakan derivat dari ketahanan nasional, ketahanan tata pemerintahan daerah dapat diartikan sebagai kondisi dinamik suatu pemerintahan daerah yang meliputi segenap aspek kehidupan yang terintegrasi serta berisi keuletan dan ketangguhan yang mengandung kemampuan untuk mengembangkan kekuatan daerahnya dalam menghadapi dan mengatasi segala tantangan, ancaman, hambatan, dan gangguan yang datang dari luar negeri atau dari dalam negeri guna menjamin identitas, integritas, serta kelangsungan hidup bangsa dan negara dalam mencapai tujuan daerah dan tujuan nasional.

Pelaksanaan e-procurement yang tangguh dapat terwujud apabila dalam pelaksanaannya mampu memenuhi tujuan dari penerapan e-procurement sesuai Perpres No. 54 tahun 2010. Tujuan tersebut bisa dijadikan salah satu indikator dalam ketahanan tata pemerintahan daerah, sebagaimana dijelaskan dalam Peraturan Presiden Nomor 54 Tahun 2010 tentang Pengadaan Barang dan Jasa Pemerintah pada Pasal 107, yaitu: meningkatkan transparansi dan akuntabilitas; meningkatkan akses pasar dan persaingan usaha yang sehat; memperbaiki tingkat efisiensi proses pengadaan; mendukung proses monitoring dan audit; memenuhi kebutuhan akses informasi yang realtime.

\section{Penerapan Prinsip e-Procurement Di Kabupaten Penajam Paser Utara}

Tabel 1 menunjukkan frekuensi pilihan jawaban dari responden untuk prinsip-prinsip dalam penerapan e-procurement di Kabupaten Penajam Paser Utara. Pilihan jawaban tertinggi yaitu jawaban setuju sebesar 2420 atau 68,81 persen, kemudian diikuti jawaban sangat setuju sebesar 650 atau 18,48 persen, jawaban raguragu sebesar 375 atau 10,66 persen, dan jawaban tidak setuju sebesar 72 atau 2,05 persen.

Hasil perhitungan tingkat persepsi responden menunjukkan angka sebesar 3517 atau 78,50 persen. Angka ini jika dikonversi pada skala interval maka terletak pada rentang lebih dari 2390 artinya menurut responden penerapan prinsip e-procurement di Kabupaten Penajam Paser Utara berada pada kondisi tinggi.

\section{Kendala Penerapan e-Procurement Di Kabupaten Penajam Paser Utara}

Tabel 2 menunjukkan frekuensi pilihan jawaban dari responden untuk kendala dalam penerapan e-procurement di Kabupaten Penajam Paser Utara. Pilihan jawaban tertinggi yaitu jawaban setuju sebesar 636 atau 66,60 persen, kemudian diikuti jawaban ragu-ragu sebesar 156 atau 16,34 persen, jawaban tidak setuju sebesar 148 atau 15,50, dan sangat setuju sebesar 15 atau 1,57 persen.

Hasil perhitungan tingkat persepsi responden menunjukkan angka sebesar 955 atau 66,32 persen. Angka ini jika dikonversi pada skala interval maka terletak pada 
rentang lebih dari 768 artinya menurut responden bahwa kendala dalam penerapan e-procurement di Kabupaten Penajam Paser Utara berada pada kondisi tinggi.

\section{Strategi Dalam Mengatasi Kendala}

Pertama, Kelembagaan ULP yang Berdiri Sendiri. Berdasarkan temuan lapangan, ULP yang dibentuk melekat pada unit yang sudah ada membawa dampak yang kurang baik bagi kelancaran kebijakan e-procurement. Oleh karena itu, sudah saatnya Pemerintah Kabupaten Penajam Paser Utara memiliki ULP yang bersifat permanen dan dapat berdiri sendiri. Berdiri sendiri maksudnya adalah ULP dibentuk dalam unit struktural tersendiri yang pembentukannya berpedoman kepada Peraturan Pemerintah No. 41 Tahun 2007 tentang Organisasi Perangkat Daerah. Dengan demikian ULP dapat diisi oleh orang-orang yang profesional dan berkompetensi tinggi karena bekerja sesuai dengan tupoksinya sehingga proses pengadaan secara elektronik dapat lebih efektif, efesien, bertanggung jawab dan transparan.

Kedua, Peningkatan Infrastruktur Pendukung e-Procurement. ULPdi Kabupaten PPU telah dibekali dengan fasilitas yang cukup memadai, kendati demikian masih perlu dibenahi atau ditingkatkan fasilitasnya guna mendukung peningkatan kinerja para pegawai. Fasilitas infrastruktur pendukung yang perlu ditingkatkan yaitu penyediaan mesin generator khusus, komputer untuk setiap anggota disertai scanner dan penghancur kertas, fasilitas konektifitas internet, pembuatan sekat antar komputer di ruangan bidding room, seluruh ruangan ULP sebaiknya dilengkapi oleh CCTV agar mempermudah monitoring dan evaluasi dalam penyelenggaraan e-procurement.

Ketiga, Pengembangan SDM. Sistem e-procurement yang dibangun tidak secara otomatis mengubah budaya kerja para pengelola e-procurement. Agar transparansi berhasil diwujudkan melalui e-procurement maka mental manusia yang menyelenggarakan sistem e-procurement ini harus dibangun agar memiliki kapasitas, kapabilitas, dan komitmen yang kuat serta integritas dalam mengimplementasikan e-procurement sebagaimana yang diamanahkan dalam peraturan-peraturan.

\section{Penerapan e-Procurement Dan Ketahanan Tata Pemerintahan Daerah}

Berdasarkan penelitian yang telah dilakukan, dapat diketahui kondisi perwujudan

Tabel 1 Analisis Penerapan Prinsip e-Procurement

\begin{tabular}{lcccccc}
\hline \multirow{2}{*}{ Variabel } & STS & TS & $\mathbf{R}$ & $\mathbf{S}$ & SS & \multirow{2}{*}{ Total } \\
\cline { 2 - 5 } & $\mathbf{1}$ & $\mathbf{2}$ & $\mathbf{3}$ & $\mathbf{4}$ & $\mathbf{5}$ & \\
\hline Efisiensi & 0 & 0 & 8 & 104 & 48 & 160 \\
Efektifitas & 0 & 8 & 53 & 91 & 8 & 160 \\
Adil dan Tidak Diskriminatif & 0 & 14 & 12 & 87 & 15 & 128 \\
Transparansi & 0 & 0 & 9 & 107 & 12 & 128 \\
Terbuka dan Bersaing & 0 & 10 & 27 & 124 & 31 & 192 \\
Akuntabilitas & 0 & 4 & 16 & 92 & 16 & 128 \\
Jumlah & 0 & 36 & 125 & 605 & 130 & 896 \\
Total (Skor x Jumlah) & 0 & 72 & 375 & 2420 & 650 & $\mathbf{3 5 1 7}$ \\
Persentase & 0 & 2,05 & 10,66 & 68,81 & 18,48 & 100 \\
\hline
\end{tabular}

Sumber: Data 2014 (Diolah) 
Rahmat Hidayat -- Penerapan E-Procurement Dalam Proses Pengadaan Barang Dan Jasa Pemerintah Guna Mendukung Ketahanan Tata Pemerintahan Daerah (Studi Pada Unit Layanan Pengadaan Barang Dan Jasa

Pemerintah Kabupaten Penajam Paser Utara Provinsi Kalimantan Timur)

Tabel 2 Analisis Kendala Penerapan e-Procurement

\begin{tabular}{lcccccc}
\hline \multirow{2}{*}{ Variabel } & STS & TS & R & S & SS & \multirow{2}{*}{ Total } \\
\cline { 2 - 5 } & $\mathbf{1}$ & $\mathbf{2}$ & $\mathbf{3}$ & $\mathbf{4}$ & $\mathbf{5}$ & \\
\hline Kelembagaan ULP & 0 & 1 & 3 & 25 & 3 & 32 \\
Infrastruktur & 0 & 21 & 14 & 61 & 0 & 96 \\
SDM & 0 & 52 & 35 & 73 & 0 & 160 \\
Jumlah & 0 & 74 & 52 & 159 & 3 & 288 \\
Total (Skor x Jumlah) & 0 & 148 & 156 & 636 & 15 & 955 \\
Persentase & 0 & 15,50 & 16,34 & 66,60 & 1,57 & 100 \\
\hline
\end{tabular}

Sumber: Data 2014 (Diolah)

penerapan e-procurement dalam mendukung ketahanan tata pemerintahan daerah di Kabupaten Penajam Paser Utara, yaitu sebagai berikut:

Pertama, Meningkatkan Transparansi dan Akuntabilitas. Penerapan e-procurement dalam pengadaan barang dan jasa di Kabupaten Penajam Paser Utara telah menunjukkan adanya peningkatan transparansi dan akuntabilitas dibanding pengadaan barang dan jasa secara manual. Peningkatan transparansi dan akuntabilitas dapat dilihat dari persepsi positif para responden dan informan mengenai penerapan indikator transparansi dan akuntabilitas yakni sebesar 80,47 persen dan 78,75 persen sehingga masuk dalam kategori tinggi. Artinya para responden menyetujui bahwa prinsip transparansi dan akuntabilitas telah dilaksanakan dalam e-procurement di Kabupaten Penajam Paser Utara.

Kedua, Meningkatkan Akses Pasar dan Persaingan Usaha yang Sehat. Penerapan e-procurement di Kabupaten Penajam Paser Utara telah mampu meningkatkan persaingan usaha yang sehat diantara para penyedia barang dan jasa. Hal ini ditandai dengan penerapan salah satu prinsip e-procurement yakni prinsip terbuka dan bersaing. Berdasarkan hasil kuesioner dan wawancara menunjukkan prinsip terbuka dan bersaing telah dilaksanakan dalam proses e-procurement di Kabupaten Penajam Paser Utara. Persepsi para responden dan informan menyatakan setuju bahwa penerapan prinsip terbuka dan bersaing telah dilaksanakan dengan baik, dengan persentase indikator sebesar 78,33 persen.

Ketiga, Memperbaiki Tingkat Efisiensi Proses Pengadaan. Berdasarkan hasil penyebaran kuesioner dan wawancara, dapat diketahui persepsi para responden dan informan mengenai penerapan prinsip e-procurement menyatakan setuju bahwa e-procurement telah mampu menciptakan efisiensi dalam pengadaan barang dan jasa pemerintah, dengan persentase indikator sebesar 85 persen. Indikator prinsip efisiensi dalam e-procurement yaitu biaya proses dan administrasi semakin efisien, kecepatan dalam pengadaan barang dan jasa, kemudahan dalam pengadaan barang dan jasa, penghematan anggaran, serta capaian hasil dan sasaran dengan kualitas yang maksimum.

Keempat, Mendukung Proses Monitoring dan Audit. Berdasarkan hasil penelitian di Kabupaten Penajam Paser Utara, tujuan e-procurement untuk mendukung proses monitoring dan audit telah tercapai. Hal ini ditandai bahwa semua data mengenai pengadaan barang dan jasa atau biasa disebut lelang, akan tersimpan terus dalam Sistem Pengadaan Barang dan Jasa (SPSE) dan website, sehingga memudahkan KPK, BPK, Lembaga Kebijakan Pengadaan Barang 
dan jasa Pemerintah (LKPP), BPKP, dan Inspektorat untuk mengawasi dan memeriksa pengadaan barang dan jasa atau lelang.

Kelima, Memenuhi Kebutuhan Akses Informasi secara Real Time. Sesuai hasil penelitian di Kabupaten Penajam Paser Utara, tujuan e-procurement untuk memenuhi kebutuhan akses informasi yang realtime telah tercapai. Hal ini dapat dilihat dari pengadaan melalui e-procurement, informasi yang diperlukan tentang pengadaan barang dan jasa dapat diperoleh setiap saat. Semua pihak dengan mudah dapat mengakses portal pengadaan melalui media internet.

\section{SIMPULAN}

Berdasarkan uraian di atas dapat ditarik simpulan sebagai berikut:

Pertama, penerapan prinsip e-procurement di Kabupaten Penajam Paser Utara secara umum sudah berjalan sesuai peraturan yang berlaku namun masih terdapat beberapa kendala dalam penerapannya. Hal ini terlihat dari hasil pengujian penerapan prinsip e-procurement kepada 32 orang anggota ULP Kabupaten PPU menggunakan skala Likert. Mayoritas responden menyatakan setuju bahwa prinsip-prinsip e-procurement telah diterapkan dalam pelaksanaan e-procurement di Kabupaten Penajam Paser Utara, dengan rata-rata persentase indikator sebesar 78,50 persen dan berada pada kondisi tinggi.

Kedua, kendala-kendala yang dihadapi dalam penerapan e-procurement di Kabupaten Penajam Paser Utara, adalah permasalahan kelembagaan ULP, keterbatasan infrastruktur e-procurement, dan kendala sumber daya manusia. Strategi dalam mengatasi kendala penerapan e-procurement guna mendukung ketahanan tata pemerintahan daerah di
Kabupaten Penajam Paser Utara, yakni: kelembagaan ULP yang berdiri sendiri, peningkatan infrastruktur pendukung e-procurement, dan pengembangan SDM.

Ketiga, adapun wujud e-procurement dalam mendukung ketahanan tata pemerintahan daerah yaitu: meningkatkan transparansi dan akuntabilitas; meningkatkan akses pasar dan persaingan usaha yang sehat; memperbaiki tingkat efisiensi proses pengadaan; mendukung proses monitoring dan audit; memenuhi kebutuhan akses informasi yang real time.

Keempat, Pemerintah Kabupaten Penajam Paser Utara bisa dikatakan berhasil menerapkan prinsip serta mencapai tujuan e-procurement, akan tetapi masih terdapat beberapa kendala dalam pelaksanaannya. Oleh karena itu, ketahanan tata pemerintahan daerah di Kabupaten Penajam Paser Utara dikategorikan cukup tangguh.

Selanjutnya direkomendasikan hal-hal sebagai berikut:

Pertama, ULP Kabupaten Penajam Paser Utara adalah lembaga ad hoc yang dibentuk melekat pada unit yang sudah ada, yaitu bagian pembangunan sekretariat Kabupaten PPU. Hal ini membawa dampak yang kurang baik bagi kelancaran kebijakan e-procurement. Oleh karena itu, sudah saatnya Pemerintah Kabupaten Penajam Paser Utara memiliki ULP yang bersifat permanen dan dapat berdiri sendiri. Dengan demikian ULP dapat diisi oleh orang-orang yang profesional dan berkompetensi tinggi karena bekerja sesuai dengan tupoksinya sehingga proses pengadaan secara elektronik dapat lebih efektif, efesien, bertanggung jawab dan transparan.

Kedua, perlu ditingkatkan pelaksanaan komunikasi baik antar Satuan Kerja Perangkat Daerah (SKPD) maupun peserta penyedia 
Rahmat Hidayat -- Penerapan E-Procurement Dalam Proses Pengadaan Barang Dan Jasa Pemerintah Guna Mendukung Ketahanan Tata Pemerintahan Daerah (Studi Pada Unit Layanan Pengadaan Barang Dan Jasa Pemerintah Kabupaten Penajam Paser Utara Provinsi Kalimantan Timur)

barang dan jasa/masyarakat secara luas dalam pelaksanaan e-procurement dimana informasi harus disampaikan dengan sejelas-jelasnya, setepat-tepatnya dan seakurat mungkin serta dapat dipahami agar tidak terjadi penyimpangan-penyimpangan.

Ketiga, dalam rangka pelaksanaan tugas selalu memperhatikan peraturan-peraturan yang berlaku, selalu memperhatikan dan mengevaluasi sumber daya aparatur serta selalu diupayakan peningkatan-peningkatan dan kemampuan agar dalam pelaksanaan setiap tugas baik yang berkaitan dengan pelaksanaan e-procurement maupun tugas lain dapat dihandalkan sebagai suatu sumber kekuatan yang positif dalammencapai good governance sehingga dapat mewujudkan ketangguhan dalam ketahanan tata pemerintahan daerah.

\section{DAFTAR PUSTAKA}

Andrianto, Nico, 2007, Good e-Government: Transparansi dan Akuntabilitas Publik Melalui e-Government. Malang: Banyumedia Publishing.

Arikunto, Suharsimi, 2008, Metodelogi penelitian, Yogyakarta: Bina Aksara.

Djojoesoekarto, Agung, 2008, e-Procurement di Indonesia, Pengembangan Layanan Pengadaan Barang dan Jasa Pemerintah Secara Elektronik, Jakarta : Kemitraan. Ghiani, G., Laporte, G., \& Musmanno, R., 2004,Introduction to Logistics Systems Planning and Control, England: John Wiley.

Indonesia, 2005, Prinsip Dasar Kebijakan \& Kerangka Hukum Pengadaan Barang \& Jasa, Jakarta : Indonesian Procurement Watch.

Miles, Matthew dan Huberman, A. Michael, 1992, Analisis Data Kualitatif: Buku
Sumber Tantang Metode-Metode Baru. Jakarta:UI Press.

Narbuko,Cholid \& H.Abu Achmadi. 2005. Metodologi Penelitian. Jakarta: Bumi Aksara.

Subagyo, P. Joko, 2006, Metode Penelitian Dalam Teori Dan Praktek, Jakarta: Rineka Cipta

Sukmadinata, Nana S., 2007, Landasan Psikologi Proses Pendidikan. Bandung: Remaja Rosdakarya.

Sutedi, Adrian, 2012, Aspek Hukum Pengadaan Barang \& Jasa dan Berbagai Permasalahannya. Ed. 2, Jakarta: Sinar Grafika.

\section{Undang-Undang dan Peraturan:}

UU.No.7 Tahun 2002

Peraturan Presiden Republik Indonesia Nomor 54 Tahun 2010

Peraturan Presiden Republik Indonesia Nomor 26 Tahun 2012

Peraturan Pemerintah No. 45 Tahun 2007.

\section{Internet:}

http://www.korankaltim.com/pemkab-ppusempurnakan-e-procurement/(diakses 20 Juni 2014)

http://m.inilah.com/news/detail/1777007/ oknum-ulp-ppu-diduga-atur-pemenanglelang(diakses pada tanggal 5 November 2014)

https://harianmahakam.wordpress. com/2014/10/25/dprd-penajam-paserutara-intervensi-layanan-pengadaansecara-elektronik-lpse/. (diakses pada tanggal 5 November 2014)

http://www.korankaltim.com/sejumlah-lelangproyek-lamban/. (diakses pada tanggal 5 November 2014) 